\title{
Altered chicken thyroid hormone metabolism with chronic GH enhancement in vivo: consequences for skeletal muscle growth
}

\author{
R Vasilatos-Younken, Y Zhou, X Wang, J P McMurtry ${ }^{1}$, \\ R W Rosebrough', E Decuypere ${ }^{2}$, N Buys ${ }^{2}$, V M Darras², \\ $S$ Van der Geyten ${ }^{2}$ and F Tomas ${ }^{3}$ \\ Department of Poultry Science, Pennsylvania State University, University Park, Pennsylvania 16802, USA \\ ${ }^{1}$ Growth Biology Laboratory, Livestock and Poultry Science Institute, USDA-ARS, Beltsville, Maryland 20705, USA \\ ${ }^{2}$ Leuven Poultry Research Group, K. U. Leuven, Heverlee 3001, Belgium \\ ${ }^{3}$ Cooperative Research Center for Tissue Growth and Repair, Adelaide, South Australia, Australia \\ (Requests for offprints should be addressed to R Vasilatos-Younken; Email: rxv@psu.edu)
}

\begin{abstract}
In contrast to most vertebrates, $\mathrm{GH}$ reportedly has no effect upon somatic growth of the chicken. However, previous studies employed only one to two dosages of the hormone, and limited evidence exists of a hyperthyroid response that may confound its anabolic potential. This study evaluated the effects of $0,10,50,100$ and $200 \mu \mathrm{g} / \mathrm{kg}$ body weight per day chicken GH (cGH) (0-200 GH) infused i.v. for 7 days in a pulsatile pattern to immature, growing broiler chickens (9-10 birds/dosage). Comprehensive profiles of thyroid hormone metabolism and measures of somatic growth were obtained.

Overall (average) body weight gain was reduced 25\% by $\mathrm{GH}$, with a curvilinear, dose-dependent decrease in skeletal (breast) muscle mass that was maximal (12\%) at $100 \mathrm{GH}$. This profile mirrored GH dose-dependent decreases in hepatic type III deiodinase (DIII) activity and increases in plasma tri-iodothyronine $\left(\mathrm{T}_{3}\right)$, with both also maximal (74 and 108\% respectively) at $100 \mathrm{GH}$. No effect on type I deiodinase was observed. At the maximally effective dosage, hepatic DIII gene expression was reduced $44 \%$ versus controls. Despite dose-dependent, fold-increases in hepatic IGF-I protein content, circulating IGF-I was not altered with GH infusion, suggesting
\end{abstract}

impairment of hepatic IGF-I release. Significant, GH dose-dependent increases in plasma non-esterified fatty acid and glucose, and overall decreases in triacylglycerides were also observed. At $200 \mathrm{GH}$, feed intake was significantly reduced $(19 \% ; P<0 \cdot 05)$ versus controls; however, additional control birds pair-fed to this level did not exhibit any responses observed for GH-treated birds.

The results of this study support a pathway by which GH impacts on thyroid hormone metabolism beginning at a pretranslational level, with reduced hepatic DIII gene expression, translating to reduced protein (enzyme) expression, and reflected in a reduced level of peripheral $\mathrm{T}_{3}$-degrading activity. This contributes to decreased conversion of $T_{3}$ to its inactive form, thereby elevating circulating $\mathrm{T}_{3}$ levels. The hyper- $\mathrm{T}_{3}$ state leads to reduced net skeletal muscle deposition, and may impair release of GH-enhanced, hepatic IGF-I.

In conclusion, GH has significant biological effects in the chicken, but profound metabolic actions predominate that may confound positive, IGF-I-mediated skeletal muscle growth.

Journal of Endocrinology (2000) 166, 609-620

\section{Introduction}

Growth hormone (GH) is considered essential for postnatal somatic growth in virtually all vertebrate species as diverse as fish (Sato et al. 1988, Rahman et al. 1998) and domestic mammals (for review see Etherton \& Bauman 1998). The magnitude of this effect is greatest for teleosts, where transgenic models exhibit over 13-fold larger body size than non-transgenic controls (Du et al. 1992).

Among all species in which $\mathrm{GH}$ action has been studied, there are two apparent anomalies that have escaped

conclusive explanation. The guinea pig has long been recognized as exhibiting GH-independent growth, in so far as hypophysectomy does not reduce growth rate, and pituitary extracts do not affect growth of either hypophysectomized or pituitary-intact animals (Mitchell et al. 1954, Clayton \& Worden 1960, Baumann 1997).

A less-recognized aberrant $\mathrm{GH}$ model is the domestic chicken. A general conclusion frequently reported in the literature is that exogenous GH has no effect on the growth of modern, commercial strains of meat-type chickens (i.e. broiler), and this is frequently attributed to 
the speculation that the modern broiler has reached its genetic potential for maximal growth. However, exogenous GH fails to improve growth even in slow-growing, random-bred lines that have not been subjected to intense genetic selection for growth (Peebles et al. 1988).

A hallmark of the anabolic effect of $\mathrm{GH}$ in all GHresponsive species is increased skeletal muscle growth, mediated via the action of insulin-like growth factor-I (IGF-I). Studies employing pituitary-derived, as well as recombinant chicken $\mathrm{GH}(\mathrm{cGH})$ administered to pituitary-intact birds, have failed to demonstrate a consistent, significant increase in circulating IGF-I, or significant positive muscle growth response in immature, growing broilers (for review see Vasilatos-Younken 1999). Limiting the scope of these studies have been practical constraints in experimental design, most importantly that, in all cases, only one or two dosages of the hormone have been employed. Previous studies from our laboratory have also demonstrated that, at GH dosages at which significant metabolic responses have been obtained, evidence of a hyperthyroid effect of $\mathrm{GH}$ has been observed, which may limit the anabolic potential of the hormone (for review see Vasilatos-Younken \& Scanes 1991).

In the present study, a comprehensive GH doseresponse study was conducted in which recombinant cGH was administered in a physiologically appropriate manner (pulsatile, intravenous infusion) to sexually immature, growing, broiler chickens during the period of late posthatch development. In addition to measurement of somatic growth (body weight gain, longitudinal bone growth, skeletal muscle mass, etc.), comprehensive assessment of components of the thyroid hormone axis were evaluated to provide a more complete profile of potential changes in thyroid hormone metabolism attendant with $\mathrm{GH}$ enhancement. It was our hypothesis that GH would elicit a positive growth response, including a measurable increase in skeletal muscle deposition, at a lower dosage than previously utilized. At higher dosages, the metabolic effects of the hormone (as reflected by alterations in thyroid hormone metabolism) would predominate, which might limit further the anabolic potential of GH.

\section{Materials and Methods}

All animal procedures were approved by Pennsylvania State University Institutional Animal Care and Use Committee under protocol no. 89R1389G197.

Female broilers were surgically prepared with jugular vein catheters for chronic, intravenous delivery of cGH (Cravener \& Vasilatos-Younken 1989). When birds were 8 weeks of age (late post-hatch, juvenile), cGH was infused in a pulsatile pattern for 7 days at one of five dosages $(0,10,50,100$ or $200 \mathrm{~g} / \mathrm{kg}$ body weight $(\mathrm{BW})$ per day) (ten birds/dosage) and feed intake (FI) was monitored daily. The infusion protocol has been described previously
(Vasilatos-Younken et al. 1988), and is based on a pulse interval $(90 \mathrm{~min})$ and duration $(60 \mathrm{~min})$ that replicate the endogenous pattern of $\mathrm{GH}$ secretion in sexually immature, growing broilers. To control for possible contributions of reduced FI on measured responses, pair-fed groups for GH treatments were established. Pair-feeding of vehicleinfused birds was accomplished by restricting their feed to the identical level of that consumed by the GH treatment groups; the latter group exhibited significantly reduced FI in comparison to controls.

\section{Animal studies}

Animals All birds used in these studies were immature, broiler-strain females reared at Pennsylvania State University, Poultry Education and Research Center, and maintained under a 16-h light:8-h darkness cycle throughout. Birds were fed a high-protein, micronutrient-fortified broiler feed $(30 \%$ crude protein, $0 \cdot 78 \%$ methionine, $1 \cdot 57 \%$ lysine, $3200 \mathrm{kcal}$ metabolizable energy $/ \mathrm{kg}$, calculated analysis), and water was provided ad libitum from hatching through termination of the studies, except prior to surgery and during pair-feeding as indicated.

Surgical procedures At 6 weeks of age, birds were acclimated to individual cages in a temperature- and light-controlled room for 6 days. Feed and water were then withheld for $12-15 \mathrm{~h}$ in preparation for surgical catheterization. Birds were anesthetized with sodium pentobarbitol $(65 \mathrm{mg} / \mathrm{ml} ; 0.56 \mathrm{ml} / \mathrm{kg} \mathrm{BW}$ total dosage, i.v.). Catheters were inserted into the right jugular vein as described previously (Cravener \& Vasilatos-Younken 1989). Each catheterized bird was maintained in a harness/spring tether/fluid swivel system to allow for unrestricted, $360^{\circ}$ movement, and connected to a microprocessor controlled infusion pump (Model AS20A; Travenol Laboratories, Hookset, NH, USA) (Cravener \& Vasilatos-Younken 1989). Birds were allowed 3-6 days of postoperative recovery, and normal, pre-surgical behavior, FI and BW gain were confirmed prior to initiation of infusions at 8 weeks of age. Infusions were conducted in two experimental replicates over time, approximately 3 weeks apart, with every treatment included in each experiment.

\section{Dosage calculations and treatment administration} Over the developmental period prior to sexual maturity, plasma GH concentrations in broilers similar to those used in the present study can range from $<10.0 \mathrm{ng} / \mathrm{ml}$ (baseline troughs) to over $100 \mathrm{ng} / \mathrm{ml}$ (secretory peaks) (Vasilatos-Younken \& Zarkower 1987, Johnson 1988, $\mathrm{R}$ Vasilatos-Younken, unpublished data). A series of dosages $(0,10,50,100$ and $200 \mu \mathrm{g} / \mathrm{kg} \mathrm{BW}$ per day) was chosen that was calculated to result in circulating concentrations over this range, and to include the approximate dosage of $\mathrm{cGH}$ that was estimated in a previous study to be 
maximally effective in terms of metabolic responses $(123 \mu \mathrm{g} / \mathrm{kg} \mathrm{BW}$ per day; Vasilatos-Younken et al. 1988). Birds were selected to be 8 weeks of age at the initiation of infusions, because at this time endogenous GH secretion is low and circulating concentrations are barely detectable $(<1 \cdot 0 \mathrm{ng} / \mathrm{ml})$. This was to avoid superimposing exogenous hormone pulses on pre-existing (endogenous), highamplitude secretory peaks, as would occur at very young ages. It was felt that the latter scenario would result in a refractory state, characterized by responses suggestive of a lack of GH action, as reported previously (Moellers \& Cogburn 1995).

The cGH preparation used was recombinantly derived (Lucky Biotech, Seoul, Republic of Korea) and contained $<20$ endotoxin units/mg bacterial endotoxin. It was identical in immunological potency to a pituitary preparation purified in our laboratory and previously described (lot no. RVY03; Cravener \& Vasilatos-Younken 1989). The biological potency of the recombinant preparation in a hypophysectomized rat bioassay was $0.8 \mathrm{IU} / \mathrm{mg}$ as measured by weight gain, and $1.2 \mathrm{IU} / \mathrm{mg}$ as measured by widening of the epiphyseal growth plate, which are also similar to values for the pituitary preparation, as previously reported (Cravener \& Vasilatos-Younken 1989). GH was dissolved in a bicarbonate-buffered saline solution containing $0.025 \mathrm{M} \mathrm{NaHCO}_{3}$ and $0.025 \mathrm{M} \mathrm{Na}_{2} \mathrm{CO}_{3}, \mathrm{pH}$ $9 \cdot 4$, plus $0 \cdot 1 \%$ chicken serum albumin. Infusion pumps delivered either the appropriate $\mathrm{GH}$ solution or vehicle (buffer as described above) over a 2-min period every $90 \mathrm{~min}, 24 \mathrm{~h} /$ day $(0.8 \mathrm{ml}$ total volume/bird per day) for 7 consecutive days. Thus, 16 pulses or peaks per $24-\mathrm{h}$ period were produced. New, disposable sterile syringes containing fresh $\mathrm{cGH}$ and vehicle solutions were loaded into the pumps daily.

Data collection FI was measured daily throughout the study. Blood samples were collected by brachial venipuncture on the final day of infusion, immediately following a $\mathrm{GH}$ pulse, to determine $\mathrm{GH}$ peak amplitudes achieved by infusion. Heparinized blood samples were placed on ice and processed immediately. Plasma was obtained by centrifugation, aliquoted to multiple vials, and stored at $-80{ }^{\circ} \mathrm{C}$ until assayed. The patency of each intravenous catheter was verified at the termination of infusion, and any bird for which the catheter was not intact and functioning was eliminated from the data set. Animals were killed by rapid decapitation and organs and tissues excised immediately (Nickel et al. 1977). Liver samples were rapidly frozen in liquid nitrogen and stored at $-80{ }^{\circ} \mathrm{C}$ for later analysis.

\section{Plasma hormones and metabolites}

Plasma GH was determined by a homologous cGH radioimmunoassay (RIA) as previously described (Vasilatos-Younken 1986). Plasma thyroxine $\left(T_{4}\right)$ and tri-iodothyronine $\left(\mathrm{T}_{3}\right)$ were measured as previously described (Vasilatos-Younken et al. 1997). Plasma insulin, IGF-I and IGF-II were measured as described by McMurtry et al. (1983, 1994, 1998), and tissue IGF-I was measured as described by Rosselot et al. (1995). McMurtry et al. (1994) demonstrated that chicken IGF-binding proteins (IGFBPs) are acid-labile, so that interference of IGF-I detection by IGFBPs is not a problem using the indicated method of acid/ethanol extraction. Plasma glucagon was determined as previously described (Allen \& McMurtry 1984) using reagents purchased from Linco Research, Inc. (St Charles, MO, USA). Plasma glucose, triacylglycerides, uric acid (Bulletin nos 16UV, 335-B, and 685; Sigma Chemical Co., St Louis, MO, USA), and non-esterified fatty acids (NEFA) (NEFA-C; Wako Chemical Co., Dallas, TX, USA) were determined with commercially available kits.

\section{Muscle free 3-methyl histidine content}

A subsample (40-50 g) of breast muscle was homogenized to the consistency of fine talcum powder by grinding frozen samples together with dry ice in a stainless steel micro-mill. The dry ice was allowed to sublimate and 100-200 mg of the frozen powder was extracted with $2.5 \mathrm{ml} \mathrm{2} \%$ perchloric acid (PCA). Muscle free 3-methyl histidine was determined in PCA extracts by the method of Wassner et al. (1980), using 3-ethyl histidine as an internal standard.

\section{Hepatic deiodinase activity}

For determination of hepatic type I (DI) and III (DIII) iodothyronine deiodinase activities, liver microsomal fractions were prepared and assayed as described by Darras et al. (1992). Final incubations were in a total volume of $200 \mu \mathrm{l}$. For DI activity, final incubation mixtures contained $1 \mu \mathrm{M}$ reverse $\mathrm{T}_{3}\left(\mathrm{rT}_{3}\right), 50000$ c.p.m./tube $\left[3^{\prime}, 5^{\prime}{ }_{-}^{125} \mathrm{I}\right] \mathrm{rT}_{3}$ (Amersham Life Science, Inc., Arlington Heights, IL, USA), $100 \mu \mathrm{g} / \mathrm{ml}$ microsomal liver protein, $2 \mathrm{mM}$ EDTA, and $5 \mathrm{mM}$ dithiothreitol (DTT), and were incubated for $30 \mathrm{~min}$ at $37^{\circ} \mathrm{C}$. For DIII activity, incubations contained $1 \mathrm{nM} \mathrm{T} \mathrm{T}_{3}, 200000$ c.p.m./tube [3'${ }^{125} \mathrm{IJT}_{3}$ (Amersham Life Science, Inc.), $1 \mathrm{mg} / \mathrm{ml}$ liver microsomal protein, $1 \mu \mathrm{M} \mathrm{rT}_{3}, 0 \cdot 1 \mathrm{mM}$ propythiouracil, $2 \mathrm{mM}$ EDTA and $50 \mathrm{mM}$ DTT, and were incubated for $120 \mathrm{~min}$ at $37^{\circ} \mathrm{C}$.

\section{Hepatic DIII Northern analysis}

Chicken type I and type III iodothyronine deiodinases have been cloned and sequenced by Van der Geyten et al. (1997). $\left[\alpha-{ }^{32}\right.$ P]UTP-labeled cRNA probes were generated with the Ampliscribe T3 Transcription System (Epicentre Technologies, Biozym, Landgraaf, The Netherlands) and Northern analysis was conducted exactly 
as described previously (Van der Geyten et al. 1999a). Briefly, total liver RNA was isolated with the RNAgents total RNA isolation system (Promega, Madison, WI, USA), separated on $1 \%$ formaldehyde-agarose gels $(20 \mu \mathrm{g} / \mathrm{lane})$ and transferred onto Hybond- $\mathrm{N}^{+}$membranes (Amersham Life Science, Inc.). Blots were hybridized at $57{ }^{\circ} \mathrm{C}$ (DI) or $66{ }^{\circ} \mathrm{C}$ (DIII) with cRNA probes in NorthernMax hybridization buffer (Ambion, Sanbio, Uden, The Netherlands). Blots were washed twice for $15 \mathrm{~min}$ each time at room temperature with $1 \times \mathrm{SSC}-$ $0 \cdot 1 \%$ SDS, and twice for $1 \mathrm{~h}$ each time at $68^{\circ} \mathrm{C}$ with $0 \cdot 1 \times$ SSC $-0 \cdot 1 \%$ SDS. Autoradiographs were generated from hybridized blots and scanned to determine density of DIII mRNA bands. Ethidium bromide-stained gels were similarly scanned to verify total RNA applied. Data are expressed as DIII mRNA signal density/total RNA signal density.

\section{Statistical analyses}

Percentage organ data were transformed to arcsin square root prior to statistical analysis. Plasma GH data displayed heterogeneity of variance, and were transformed to natural log scale prior to statistical evaluation. Dose-response data were analyzed by regression analysis and linear, quadratic and cubic functions tested for each response. Initially, each response was tested for a treatment $\times$ experiment replicate interaction, which was not significant for any measurement, therefore experiments were pooled and the replicate was dropped from the model.

For informational purposes, arithmetic, least squares means (LSM) \pm standard error of the LSM are provided in figures and tables for all data, and any necessary transformations that were used are indicated.

\section{Results}

Arithmetic mean plasma GH concentrations for each dosage group are indicated in Fig. 1. Individual values within a dosage fell within a narrow range and did not overlap between groups. Natural log-transformed data followed a third order model as a function of $\mathrm{GH}$ dosage $\left(\mathrm{R}^{2}=0.89\right.$; Fig. 1).

Voluntary FI in GH-infused birds began to decline relative to controls at $100 \mu \mathrm{g} / \mathrm{kg} \mathrm{BW}$ per day $\mathrm{GH}(7 \%)$, but was significantly reduced $(19 \% ; P<0.05)$ only at the highest dosage $(200 \mu \mathrm{g} / \mathrm{kg} \mathrm{BW}$ per day). (See Wang et al. (2000) for complete profile.)

BW gain for GH-infused birds over the 7-day infusion period was reduced an average of $25 \%$ in comparison to controls $(P<0 \cdot 05)$, with a tendency towards a dosedependent decrease in weight gain (Table 1) that did not reflect FI responses as described above. Total (left plus right) kidney weight was increased an average of $14 \%$ for all $\mathrm{GH}$-treated birds versus controls $(P<0 \cdot 05)$, but this

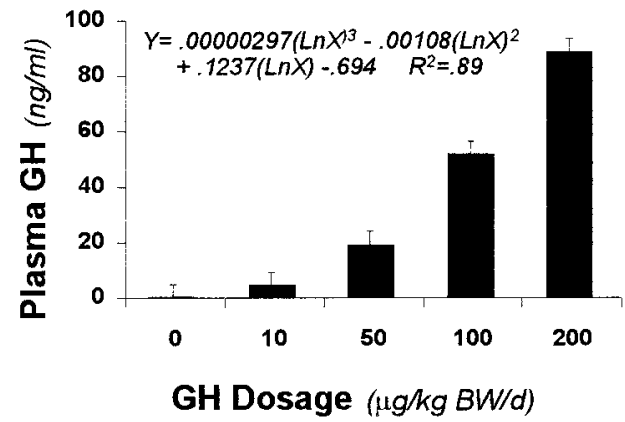

Figure 1 Mean plasma $\mathrm{GH}$ concentrations $(\mathrm{ng} / \mathrm{ml})$ in 8-week-old, female broiler chickens intravenously infused in a pulsatile pattern for 7 days with $\mathrm{cGH}$ at $0,10,50,100$ or $200 \mu \mathrm{g} / \mathrm{kg}$ BW per day. Daily doses were equally divided into sixteen $50 \mu \mathrm{l}$ pulses each infused over a 2-min period every $90 \mathrm{~min}$ for a total of $0.8 \mathrm{ml} / \mathrm{bird}$ per day. Blood samples were collected by brachial venipuncture on the final day of infusion, immediately following completion of a pulse, and represent the peak plasma concentration of the hormone achieved. Values are LSM \pm S.E. of the LSM $(n=9-10$ birds/dosage). $\mathrm{Ln}=$ natural log.

response was again not dose-dependent (Table 1). Total kidney weight as a percentage of final body weight was increased in a dose-dependent manner with GH dosage, with arcsin square root transformed data following a linear function (Fig. 2). Other measures of somatic growth were not significantly altered by GH infusion, including weight of potential GH target organs such as the liver and spleen, longitudinal bone growth (tibiotarsal length), and adipose tissue deposition (Table 1). There were no significant differences in any somatic measures between control birds and birds pair-fed to the reduced level of FI of GH-infused birds (Table 2).

Plasma triacylglyceride concentrations were reduced approximately $32 \% \quad(P<0 \cdot 05)$ with $\mathrm{GH}$ infusion, but this response was not dose-dependent (Table 3). Plasma glucagon, insulin, uric acid, IGF-I and IGF-II concentrations, muscle IGF-I content, and hepatic DI activity were not significantly altered by GH infusion (Table 3), nor were any plasma hormone or metabolite concentration, tissue IGF-I content, or hepatic iodothyronine deiodinase activities in pair-fed groups in comparison to controls (Table 4). Liver IGF-I content was significantly increased in a dose-dependent manner with GH infusion (Fig. 3).

The most dramatic, GH dose-dependent tissue response was a reduction in breast muscle mass, which followed a curvilinear (quadratic) function, with a maximal reduction of $12 \%$ after 7 days of infusion at the $100 \mu \mathrm{g} / \mathrm{kg} \mathrm{BW}$ per day dosage (Fig. 4). Percentage breast muscle was similarly reduced with GH infusion, with arcsin square roottransformed data decreased in a linear fashion with $\mathrm{GH}$ dosage (Fig. 2). The dose-dependent reduction in breast muscle mirrored a curvilinear increase in plasma $T_{3}$ concentrations, and a decrease in hepatic DIII activity, 
Table 1 Somatic measures ${ }^{1}$ following 7 days of pulsatile i.v. infusion of vehicle or cGH to 8-week-old, female broiler-strain chickens

cGH dosage $(\mu \mathrm{g} / \mathrm{kg}$ BW per day)

\begin{tabular}{|c|c|c|c|c|c|c|}
\hline & & & & & & \\
\hline & $\begin{array}{l}0 \\
(n=9)\end{array}$ & $\begin{array}{l}10 \\
(n=9)\end{array}$ & $\begin{array}{l}50 \\
(n=10)\end{array}$ & $\begin{array}{l}100 \\
(n=10)\end{array}$ & $\begin{array}{l}200 \\
(n=10)\end{array}$ & $\begin{array}{l}\text { GH } \\
\text { response }^{2}\end{array}$ \\
\hline $\begin{array}{l}\text { Measured } \\
\text { response } \\
\text { 7-day net BW gain }\end{array}$ & & & & & & \\
\hline & $485 \pm 30 \cdot 6$ & $383 \pm 30 \cdot 6$ & $388 \pm 29 \cdot 1$ & $345 \pm 29 \cdot 4$ & $330 \pm 29 \cdot 7$ & $361 \pm 14 \cdot 7^{*}$ \\
\hline (\% of initial BW) & $20 \cdot 4 \pm 1 \cdot 38$ & $15 \cdot 8 \pm 1 \cdot 38$ & $16 \cdot 2 \pm 1 \cdot 31$ & $14 \cdot 2 \pm 1 \cdot 33$ & $13 \cdot 8 \pm 1 \cdot 34$ & $15 \cdot 0 \pm 0 \cdot 66^{*}$ \\
\hline $\begin{array}{l}\text { Kidneys } \\
\text { (g) }\end{array}$ & $19 \cdot 1 \pm 0 \cdot 64$ & $21 \cdot 1 \pm 0 \cdot 64$ & $21 \cdot 4 \pm 0 \cdot 61$ & $22 \cdot 2 \pm 0 \cdot 61$ & $22 \cdot 3 \pm 0 \cdot 62$ & $21 \cdot 8 \pm 0 \cdot 31^{*}$ \\
\hline $\begin{array}{l}\text { Liver } \\
\qquad(\mathrm{g}) \\
\quad(\% \text { of final } \mathrm{BW})\end{array}$ & $\begin{array}{r}63 \cdot 4 \pm 2 \cdot 88 \\
2 \cdot 2 \pm 0 \cdot 10\end{array}$ & $\begin{array}{r}56 \cdot 8 \pm 2 \cdot 88 \\
2 \cdot 0 \pm 0 \cdot 10\end{array}$ & $\begin{array}{r}64 \cdot 5 \pm 2 \cdot 74 \\
2 \cdot 3 \pm 0 \cdot 09\end{array}$ & $\begin{array}{r}67 \cdot 1 \pm 2 \cdot 76 \\
2 \cdot 4 \pm 0 \cdot 09\end{array}$ & $\begin{array}{r}67 \cdot 5 \pm 2 \cdot 79 \\
2 \cdot 4 \pm 0 \cdot 09\end{array}$ & - \\
\hline $\begin{array}{l}\text { Spleen } \\
\quad(\mathrm{g}) \\
\quad(\% \text { of final BW) }\end{array}$ & $\begin{array}{c}4 \cdot 6 \pm 0 \cdot 65 \\
0 \cdot 16 \pm 0 \cdot 012\end{array}$ & $\begin{array}{c}5 \cdot 5 \pm 0 \cdot 35 \\
0 \cdot 19 \pm 0 \cdot 012\end{array}$ & $\begin{array}{c}4 \cdot 3 \pm 0 \cdot 33 \\
0 \cdot 15 \pm 0 \cdot 012\end{array}$ & $\begin{aligned} 5 \cdot 0 & \pm 0 \cdot 34 \\
0 \cdot 18 & \pm 0 \cdot 122\end{aligned}$ & $\begin{array}{c}4 \cdot 8 \pm 0 \cdot 34 \\
0 \cdot 17 \pm 0 \cdot 012\end{array}$ & - \\
\hline $\begin{array}{l}\text { Abdominal fatpad } \\
\text { (g) } \\
\text { (\% of final BW) }\end{array}$ & $\begin{array}{r}55 \cdot 9 \pm 4.94 \\
1 \cdot 9 \pm 0 \cdot 17\end{array}$ & $\begin{array}{r}50 \cdot 3 \pm 4 \cdot 95 \\
1 \cdot 8 \pm 0 \cdot 17\end{array}$ & $\begin{array}{r}52 \cdot 8 \pm 4 \cdot 70 \\
1 \cdot 9 \pm 0 \cdot 16\end{array}$ & $\begin{array}{r}48 \cdot 4 \pm 4 \cdot 74 \\
1 \cdot 7 \pm 0 \cdot 16\end{array}$ & $\begin{array}{r}43 \cdot 6 \pm 4 \cdot 79 \\
1 \cdot 6 \pm 0 \cdot 16\end{array}$ & - \\
\hline $\begin{array}{l}\text { Skeletal muscle mass } \\
\text { Left femur }\end{array}$ & & & & & & \\
\hline $\begin{array}{l}(\mathrm{g}) \\
(\% \text { of final BW) }\end{array}$ & $\begin{array}{r}113 \cdot 8 \pm 3 \cdot 37 \\
3 \cdot 9 \pm 0 \cdot 11\end{array}$ & $\begin{aligned} 116 \cdot 7 & \pm 3 \cdot 37 \\
4 \cdot 2 & \pm 0 \cdot 11\end{aligned}$ & $\begin{array}{r}111 \cdot 8 \pm 3 \cdot 20 \\
4 \cdot 0 \pm 0 \cdot 11\end{array}$ & $\begin{array}{r}109 \cdot 6 \pm 3 \cdot 23 \\
4 \cdot 0 \pm 0 \cdot 11\end{array}$ & $\begin{array}{r}115 \cdot 3 \pm 3 \cdot 26 \\
4 \cdot 2 \pm 0 \cdot 11\end{array}$ & - \\
\hline $\begin{array}{l}\text { Left tibiotarsus } \\
\quad(\mathrm{g}) \\
(\% \text { of final } \mathrm{BW})\end{array}$ & $\begin{array}{r}90 \cdot 0 \pm 2 \cdot 04 \\
3 \cdot 1 \pm 0 \cdot 08\end{array}$ & $\begin{array}{r}89 \cdot 1 \pm 1 \cdot 94 \\
3 \cdot 2 \pm 0 \cdot 07\end{array}$ & $\begin{array}{r}83 \cdot 7 \pm 1 \cdot 87 \\
3 \cdot 0 \pm 0 \cdot 07\end{array}$ & $\begin{array}{r}81 \cdot 0 \pm 1 \cdot 88 \\
2 \cdot 9 \pm 0 \cdot 07\end{array}$ & $\begin{array}{r}80 \cdot 9 \pm 1 \cdot 90 \\
2 \cdot 9 \pm 0 \cdot 07\end{array}$ & - \\
\hline $\begin{array}{l}\text { Tibiotarsal length } \\
(\mathrm{mm})\end{array}$ & $120 \cdot 7 \pm 1 \cdot 19$ & $121 \cdot 2 \pm 1 \cdot 26$ & $121 \cdot 0 \pm 1 \cdot 13$ & $122 \cdot 3 \pm 1 \cdot 14$ & $120 \cdot 9 \pm 1 \cdot 15$ & - \\
\hline
\end{tabular}

${ }^{1} \mathrm{LSM} \pm$ S.E. of the LSM. Tissue data expressed as a percentage of final BW (e.g. organs, muscle and adipose tissue) were converted to arcsin square root prior to statistical analysis and significant differences, where indicated, are based on the transformed data. However, untransformed means are provided above for informational purposes.

${ }^{2}$ For data indicated, there was no dose-response to $\mathrm{GH}$, therefore the main effect of treatment (GH versus control) was evaluated and the overall (mean) GH response is presented.

*Significantly different from control $(P<0 \cdot 05)$.

which were also maximal at the $100 \mu \mathrm{g} / \mathrm{kg} \mathrm{BW}$ per day dosage $\left(108 \%\right.$ increase for $\mathrm{T}_{3} ; 72 \%$ reduction in DIII activity) (Fig. 4). Plasma $\mathrm{T}_{4}$ was decreased with $\mathrm{GH}$ infusion, following a third order function, and this decrease was also maximal (49\%) at the $100 \mu \mathrm{g} / \mathrm{kg}$ BW per day dosage (Fig. 4). Hepatic DIII mRNA expression was reduced $44 \%(P<0 \cdot 05)$ by $\mathrm{GH}$ at the maximally effective dosage $(100 \mu \mathrm{g} / \mathrm{kg}$ BW per day) (Table 5$)$, whereas DIII message was increased $(29 \% ; P<0 \cdot 05)$ with feed restriction (pair-feeding) (Table 5). These results correspond to previous findings by Darras et al. (1995) and Van der Geyten et al. (1999b).

Plasma metabolites that were significantly altered by $\mathrm{GH}$ infusion in a dose-dependent manner were plasma NEFA and glucose concentrations, which were increased linearly with GH dosage (Fig. 5).

Breast muscle free 3-methyl histidine at the GH dosage that resulted in the maximal reduction in breast muscle mass $(100 \mu \mathrm{g} / \mathrm{kg} \mathrm{BW}$ per day dosage) was not significantly different from the control group (Table 5). Breast muscle free 3-methyl histidine content was also not significantly different between ad libitum fed controls and birds pairfed to the reduced level of FI of this GH dosage group (Table 5).

\section{Discussion}

An objective of the present work was to better define GH-induced alterations in the pathway of thyroid hormone metabolism that would help to elucidate $\mathrm{GH}$ action in the chicken. In interpreting the results of this study, recognition of the basic elements of this pathway and their relative expression in the chicken are relevant. The metabolically active form of thyroid hormone, 3,3',5tri-iodo-L-thyronine $\left(\mathrm{T}_{3}\right)$, is derived from extrathyroidal (in particular, hepatic) outer ring deiodination $\left(5^{\prime} \mathrm{D}\right)$ of $\mathrm{T}_{4}$ by DI and DII, whereas inactivation of $\mathrm{T}_{4}$ to $\mathrm{rT}_{3}$, and of $\mathrm{T}_{3}$ to di-iodothyronine by inner ring deiodination $(5 \mathrm{D})$ is catalyzed by DIII and DI respectively (Leonard \& Visser 

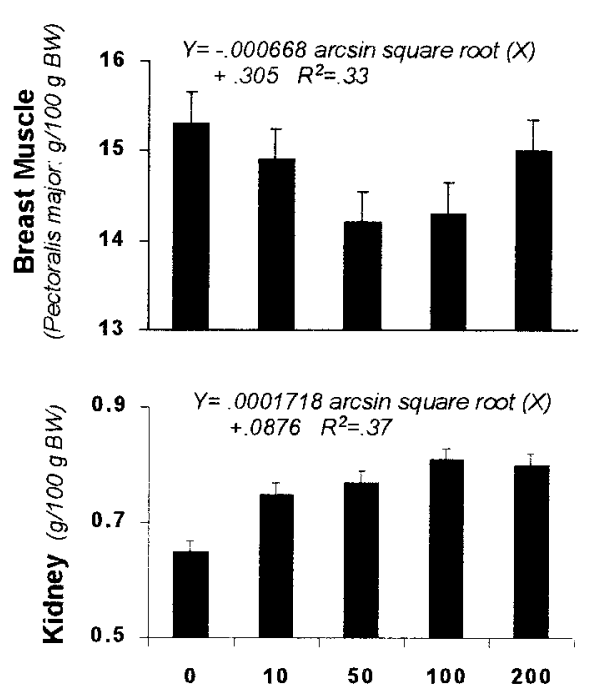

GH Dosage $(\mu \mathrm{g} / \mathrm{kg} B W / \mathrm{d})$

Figure 2 Breast muscle and kidney weights as a percentage of final BW in 8-week-old, female broiler chickens intravenously infused in a pulsatile pattern for 7 days with $\mathrm{cGH}$ at $0,10,50$, 100 or $200 \mu \mathrm{g} / \mathrm{kg}$ BW per day. Tissues were collected on the final day of infusion, immediately following completion of a pulse. Values are $\operatorname{LSM} \pm$ S.E. of the LSM ( $n=9-10$ birds/dosage).

1986). Chick embryo liver reportedly contains DI, as well as considerable amounts of DIII, but little or no DII (for review see Kuhn et al. 1993). Acute administration of GH decreases hepatic 5 DIII activity in young chickens, which decreases peripheral $\mathrm{T}_{3}$-degrading activity and, ultimately, increases circulating $\mathrm{T}_{3}$ concentrations, but appears to have no effect whatsoever on the amount of hepatic DI (Darras et al. 1992, 1993). In chick embryos, a single GH injection was shown to effect the decrease in 5 DIII at a pretranslational level (Van der Geyten et al. 1999a).

The responses in plasma thyroid hormone and hepatic deiodinase activities in the present study extend previously published findings to chronic administration of GH in late post-hatch chickens. The present data also confirm that at least one mechanism by which $\mathrm{GH}$ elevates circulating $\mathrm{T}_{3}$ is a dramatic reduction in $T_{3}$ degradation. Given that hepatic DI was not significantly altered by $\mathrm{GH}$, the observed, co-ordinated decrease in plasma $\mathrm{T}_{4}$ could be due to feedback inhibition of pituitary thyrotropin (TSH) secretion, as a result of elevated plasma $\mathrm{T}_{3}$. Increased circulating $\mathrm{T}_{3}$ in response to $\mathrm{GH}$ is observed in the human and other species, but often circumstantially assumed to result from increased conversion of $\mathrm{T}_{4}$ (deLuze \& LeLoup 1984, Wolf et al. 1989, Moller et al. 1992, Jorgensen et al. 1994, Johansson et al. 1996).

Because of the precise control possible with microprocessor-controlled, intravenous delivery in the present study, circulating concentrations of $\mathrm{GH}$ achieved over the full dose-response curve were extremely uniform within dosage groups, and non-overlapping between groups. This enhanced definition of the response curves and confidence in the profile obtained for each response. What is most apparent from the present data, and previously unrecognized, is that $\mathrm{GH}$ not only failed to enhance overall body growth at any dosage, but the nature of the response was negative. This was particularly clear from the profile for breast muscle deposition (reduced net muscle mass versus controls). Interestingly, leg muscles for $\mathrm{GH}$-treated birds in the present study were not reduced similarly to breast muscle, which may reflect differences in sensitivity of muscle fiber types. Chicken breast muscle is composed almost exclusively of white, IIB fast glycolytic fibers, whereas leg muscles reflect both type I and II red, slow oxidative fiber types (Aberle \& Stewart 1983).

The loss of breast muscle mass in the present study would appear to conflict with documented anabolic effects of exogenous $\mathrm{GH}$ demonstrated in other species (with the exception of the guinea pig, as mentioned earlier). However, the response becomes rational in light of closely mirrored responses observed in thyroid hormone metabolism (in particular, hepatic DIII and plasma $T_{3}$ ), which suggest that this negative response is secondary to a GH-induced hyper- $\mathrm{T}_{3}$ state, and not a direct, primary GH lesion. Net loss of muscle protein occurs in human patients with high serum $\mathrm{T}_{3}$ (Hasselgren et al. 1984, Morrison et al. 1988) and in experimental models of hyperthyroidism (Carter et al. 1980), and supplemental $\mathrm{T}_{3}$ reduces body weight gain in chickens (May 1980, Bowen et al. 1987, Tixier-Boichard et al. 1990).

Skeletal muscle mass is a function of the net balance in components of muscle protein turnover. In the present study, muscle 3-methyl histidine, regarded as an indicator of myofibrillar protein breakdown, was not increased in birds exhibiting the maximal degree of reduced muscle deposition (at the $100 \mu \mathrm{g} / \mathrm{kg} \mathrm{BW}$ per day GH dosage). This suggests that the decreased muscle mass was not a function of increased muscle protein catabolism. Morrison et al. (1988) also failed to detect an increase in muscle 3-methyl histidine efflux in human patients with thyrotoxicosis and net loss of skeletal muscle protein. In fact, in the latter study, evidence was provided of reduced muscle protein breakdown as well as reduced synthesis rates, which led the authors to conclude that the net loss of protein in a hyper- $\mathrm{T}_{3}$ state reflects more a decrease in muscle protein synthesis, rather than increased muscle proteolysis. As muscle protein synthesis rates were not determined in the present study, this cannot be confirmed for the $\mathrm{GH}$-induced hyper- $\mathrm{T}_{3}$ state of our birds.

It is unlikely that the reductions in breast muscle mass with $\mathrm{GH}$ infusion were due to $\mathrm{GH}$-induced decreases in FI. Although birds infused with the highest dosage of $\mathrm{GH}$ $(200 \mu \mathrm{g} / \mathrm{kg} \mathrm{BW}$ per day) exhibited significantly reduced FI (19\%), this response was not dose-dependent, as were the reductions in breast muscle mass. The latter coincided with increases in plasma $T_{3}$ concentrations over the full 
Table 2 Somatic measures ${ }^{1}$ following 7 days of pulsatile i.v. infusion of vehicle to 8-week-old, female broiler-strain chickens fed ad libitum (control) or restricted to the reduced level of voluntary feed consumption of birds infused with 100 or $200 \mu \mathrm{g} \mathrm{cGH} / \mathrm{kg}$ BW per day (pairfed-100, pairfed-200)

\begin{tabular}{|c|c|c|c|}
\hline \multirow{3}{*}{$\begin{array}{l}\text { Measured } \\
\text { response }\end{array}$} & \multicolumn{3}{|c|}{ Treatment group ${ }^{2}$} \\
\hline & $\begin{array}{l}\text { Control } \\
(n=9)\end{array}$ & $\begin{array}{l}\text { Pairfed-100 } \\
(n=9)\end{array}$ & $\begin{array}{l}\text { Pairfed-200 } \\
(n=10)\end{array}$ \\
\hline & & & \\
\hline $\begin{array}{l}\text { 7-day net BW gain } \\
\text { (g) } \\
\text { (\% of initial BW) }\end{array}$ & $\begin{array}{r}442 \pm 19 \cdot 0 \\
18 \cdot 4 \pm 0 \cdot 80\end{array}$ & $\begin{array}{r}489 \pm 18 \cdot 8 \\
20 \cdot 1 \pm 0 \cdot 79\end{array}$ & $\begin{array}{r}442 \pm 20 \cdot 0 \\
18 \cdot 3 \pm 0 \cdot 84\end{array}$ \\
\hline $\begin{array}{l}\text { Kidneys } \\
\qquad(\mathrm{g}) \\
(\% \text { of final BW) }\end{array}$ & $\begin{array}{l}18 \cdot 9 \pm 0 \cdot 46 \\
0 \cdot 66 \pm 0 \cdot 016\end{array}$ & $\begin{array}{l}19 \cdot 2 \pm 0 \cdot 45 \\
0 \cdot 66 \pm 0 \cdot 015\end{array}$ & $\begin{array}{l}18 \cdot 2 \pm 0 \cdot 48 \\
0 \cdot 64 \pm 0 \cdot 016\end{array}$ \\
\hline $\begin{array}{l}\text { Spleen } \\
\qquad(\mathrm{g}) \\
(\% \text { of final BW) }\end{array}$ & $\begin{aligned} 7 \cdot 0 & \pm 0 \cdot 62 \\
0 \cdot 24 & \pm 0 \cdot 021\end{aligned}$ & $\begin{array}{c}6 \cdot 6 \pm 0 \cdot 61 \\
0 \cdot 23 \pm 0 \cdot 021\end{array}$ & $\begin{array}{c}5 \cdot 3 \pm 0 \cdot 65 \\
0 \cdot 19 \pm 0 \cdot 022\end{array}$ \\
\hline $\begin{array}{l}\text { Liver } \\
\qquad(\mathrm{g}) \\
\text { (\% of final BW) }\end{array}$ & $\begin{array}{r}69 \cdot 5 \pm 4 \cdot 00 \\
2 \cdot 4 \pm 0 \cdot 13\end{array}$ & $\begin{array}{r}70 \cdot 3 \pm 3 \cdot 96 \\
2 \cdot 4 \pm 0 \cdot 13\end{array}$ & $\begin{array}{r}64 \cdot 8 \pm 4 \cdot 23 \\
2 \cdot 3 \pm 0 \cdot 14\end{array}$ \\
\hline $\begin{array}{l}\text { Abdominal fatpad } \\
\text { (g) } \\
\text { (\% of final BW) }\end{array}$ & $\begin{aligned} 56 \cdot 1 & \pm 4 \cdot 9 \\
2 \cdot 0 & \pm 0 \cdot 17\end{aligned}$ & $\begin{aligned} 51 \cdot 1 & \pm 4 \cdot 9 \\
1 \cdot 7 & \pm 0 \cdot 17\end{aligned}$ & $\begin{aligned} 53 \cdot 4 & \pm 5 \cdot 2 \\
1 \cdot 9 & \pm 0 \cdot 18\end{aligned}$ \\
\hline $\begin{array}{l}\text { Skeletal muscle mass } \\
\text { Left femur }\end{array}$ & & & \\
\hline $\begin{array}{l}(\mathrm{g}) \\
(\% \text { of final BW) }\end{array}$ & $\begin{array}{r}115 \cdot 4 \pm 3 \cdot 06 \\
4 \cdot 0 \pm 0 \cdot 11\end{array}$ & $\begin{array}{r}112 \cdot 5 \pm 3 \cdot 03 \\
3 \cdot 9 \pm 0 \cdot 11\end{array}$ & $\begin{array}{r}112 \cdot 8 \pm 3 \cdot 23 \\
4 \cdot 0 \pm 0 \cdot 11\end{array}$ \\
\hline $\begin{array}{l}\text { Left tibiotarsus } \\
\text { (g) } \\
\text { (\% of final BW) }\end{array}$ & $\begin{array}{r}85 \cdot 6 \pm 2 \cdot 44 \\
3 \cdot 0 \pm 0 \cdot 09\end{array}$ & $\begin{array}{r}86 \cdot 5 \pm 2 \cdot 42 \\
3 \cdot 0 \pm 0.09\end{array}$ & $\begin{array}{r}89 \cdot 3 \pm 2 \cdot 58 \\
3 \cdot 1 \pm 0 \cdot 10\end{array}$ \\
\hline $\begin{array}{l}\text { Breast } \\
\qquad(\mathrm{g}) \\
\quad(\% \text { of final } \mathrm{BW})\end{array}$ & $\begin{array}{l}432 \pm 9 \cdot 9 \\
15 \cdot 1 \pm 0 \cdot 33\end{array}$ & $\begin{array}{l}418 \pm 9 \cdot 8 \\
14 \cdot 4 \pm 0 \cdot 33\end{array}$ & $\begin{array}{r}429 \pm 10 \cdot 4 \\
15 \cdot 0 \pm 0 \cdot 49\end{array}$ \\
\hline $\begin{array}{l}\text { Tibiotarsal length } \\
(\mathrm{mm})\end{array}$ & $124 \cdot 3 \pm 1 \cdot 12$ & $122 \cdot 5 \pm 1 \cdot 11$ & $120 \cdot 8 \pm 1 \cdot 18$ \\
\hline
\end{tabular}

${ }^{1} \mathrm{LSM} \pm$ S.E. of the LSM.

${ }^{2}$ There were no significant differences among treated groups for any somatic measures $(P>0 \cdot 05)$.

dose-response curve, with both responses maximal at $100 \mu \mathrm{g} / \mathrm{kg} \mathrm{BW}$ per day GH. Also, birds pair-fed to the level of reduced FI of GH-infused birds did not exhibit significant reductions in body weight gain or breast muscle mass in comparison to controls.

GH infusion did increase kidney weight, likely reflecting the organ-specific nature of a hyper- $\mathrm{T}_{3}$ state, which is generally catabolic for skeletal muscle, but not for critical visceral organs. For example, treatment with $T_{3}$ from birth until weaning selectively enhanced all measures of cardiac growth, but significantly reduced skeletal muscle (gastrocnemius) total DNA, RNA, and total and myofibrillar protein content in rats (Moussavi 1990).

The underlying mechanism(s) by which net skeletal muscle deposition is reduced in a hyper- $\mathrm{T}_{3}$ state is (are) not known. It is generally accepted that the anabolic effects of $\mathrm{GH}$ on skeletal muscle are mediated via the actions of IGF-I, and at least partially by IGF-I produced by the liver and acting in an endocrine manner. Plasma IGF-I concentrations are partially but not totally GH-dependent in the chicken, as levels are reduced to $30-50 \%$ of normal in hypophysectomized birds and to approximately one-third normal levels in sex-linked dwarf chickens, the latter which exhibit impaired GH receptor function (for review see Vasilatos-Younken 1999). All indications are that the effects of IGF-I upon satellite cell proliferation and, thereby, postnatal muscle growth, are similar in chickens to those in mammals (for review see Vasilatos-Younken 1999). It is therefore relevant that GH failed to elevate circulating IGF-I concentrations at any dosage (as determined by a homologous RIA that ensured IGFBPs were not an interfering factor (McMurtry et al. 
Table 3 Plasma hormones and metabolites, skeletal muscle IGF-I concentrations, and hepatic type I iodothyronine deiodinase activity ${ }^{1}$ following 7 days of pulsatile i.v. infusion of vehicle or $\mathrm{cGH}$ to 8 -week-old, female broiler-strain chickens

cGH dosage ( $\mu \mathrm{g} / \mathrm{kg}$ BW per day)

\begin{tabular}{|c|c|c|c|c|c|}
\hline $\begin{array}{l}0 \\
(n=9)\end{array}$ & $\begin{array}{l}10 \\
(n=9)\end{array}$ & $\begin{array}{l}50 \\
(n=10)\end{array}$ & $\begin{array}{l}100 \\
(n=10)\end{array}$ & $\begin{array}{l}200 \\
(n=10)\end{array}$ & $\begin{array}{l}\mathrm{GH} \\
\text { response }^{2}\end{array}$ \\
\hline $145 \cdot 1 \pm 11 \cdot 79$ & $161 \cdot 0 \pm 11 \cdot 18$ & $153 \cdot 0 \pm 10 \cdot 8$ & $131 \cdot 4 \pm 10 \cdot 8$ & $148 \cdot 5 \pm 11 \cdot 5$ & - \\
\hline $2 \cdot 39 \pm 0 \cdot 364$ & $1 \cdot 77 \pm 0 \cdot 346$ & $1 \cdot 88 \pm 0 \cdot 332$ & $2 \cdot 84 \pm 0 \cdot 332$ & $2 \cdot 37 \pm 0 \cdot 355$ & - \\
\hline $7 \cdot 3 \pm 0 \cdot 82$ & $4 \cdot 1 \pm 0 \cdot 78$ & $5 \cdot 6 \pm 0 \cdot 75$ & $4 \cdot 8 \pm 0 \cdot 75$ & $6 \cdot 4 \pm 0 \cdot 80$ & - \\
\hline $116 \pm 6 \cdot 67$ & $73 \cdot 6 \pm 6 \cdot 32$ & $88 \cdot 3 \pm 6 \cdot 08$ & $77 \cdot 5 \pm 6 \cdot 08$ & $76 \cdot 1 \pm 6 \cdot 5$ & $78.9 \pm 3 \cdot 27$ * \\
\hline $10 \cdot 9 \pm 1 \cdot 02$ & $12 \cdot 7 \pm 0 \cdot 97$ & $12 \cdot 4 \pm 0 \cdot 9$ & $11 \cdot 2 \pm 0 \cdot 9$ & $14 \cdot 1 \pm 1 \cdot 00$ & - \\
\hline $22 \cdot 8 \pm 1 \cdot 05$ & $25 \cdot 9 \pm 1 \cdot 00$ & $24 \cdot 6 \pm 0.96$ & $23 \cdot 6 \pm 0 \cdot 96$ & $25 \cdot 6 \pm 1 \cdot 03$ & - \\
\hline $301 \cdot 9 \pm 120 \cdot 5$ & $138 \cdot 2 \pm 120 \cdot 5$ & $322 \cdot 8 \pm 114 \cdot 3$ & $98 \cdot 9 \pm 114 \cdot 3$ & $291 \cdot 8 \pm 114 \cdot 3$ & - \\
\hline $607 \cdot 8 \pm 169 \cdot 9$ & $868 \cdot 0 \pm 169 \cdot 9$ & $1024 \cdot 3 \pm 161 \cdot 2$ & $736 \cdot 9 \pm 161 \cdot 2$ & $944 \cdot 3 \pm 161 \cdot 2$ & - \\
\hline $117 \cdot 4 \pm 6 \cdot 74$ & $103 \cdot 1 \pm 6 \cdot 74$ & $106 \cdot 0 \pm 6 \cdot 39$ & $106 \cdot 2 \pm 6 \cdot 39$ & $99 \cdot 9 \pm 6 \cdot 39$ & - \\
\hline
\end{tabular}

${ }^{1} \mathrm{LSM} \pm$ S.E. of the LSM.

${ }^{2}$ For data indicated, there was no dose-response to $\mathrm{GH}$, therefore the main effect of treatment (GH versus control) was evaluated and the overall (mean) GH response is presented.

*Significantly different from control $(P<0 \cdot 05)$.

Table 4 Plasma hormones and metabolites, tissue IGF-I concentrations, and heaptic iodothyronine deiodinase activities ${ }^{1}$ following 7 days of pulsatile i.v. infusion of vehicle to 8-week-old, female broiler-strain chickens fed ad libitum (control) or restricted to the reduced level of voluntary feed consumption of birds infused with 100 or $200 \mu \mathrm{g} \mathrm{cGH} / \mathrm{kg}$ BW per day (pairfed-100, pairfed-200)

\section{Treatment group}

\begin{tabular}{|c|c|c|}
\hline $\begin{array}{l}\text { Control } \\
(n=9)\end{array}$ & $\begin{array}{l}\text { Pairfed-100 } \\
(n=9)\end{array}$ & $\begin{array}{l}\text { Pairfed-200 } \\
(n=10)\end{array}$ \\
\hline $147 \cdot 3 \pm 14 \cdot 05$ & $127 \cdot 7 \pm 14 \cdot 05$ & $142 \cdot 6 \pm 14 \cdot 90$ \\
\hline $1 \cdot 91 \pm 0.386$ & $2 \cdot 16 \pm 0 \cdot 386$ & $2 \cdot 76 \pm 0 \cdot 410$ \\
\hline $8 \cdot 2 \pm 0 \cdot 80$ & $8 \cdot 4 \pm 0 \cdot 80$ & $9 \cdot 1 \pm 0 \cdot 85$ \\
\hline $23 \cdot 7 \pm 0 \cdot 92$ & $23 \cdot 3 \pm 0 \cdot 92$ & $25 \cdot 1 \pm 0 \cdot 97$ \\
\hline $261 \cdot 7 \pm 8 \cdot 31$ & $261 \cdot 8 \pm 8 \cdot 31$ & $256 \cdot 5 \pm 8 \cdot 81$ \\
\hline $147 \cdot 0 \pm 11 \cdot 63$ & $158.9 \pm 11.63$ & $154 \cdot 8 \pm 12 \cdot 33$ \\
\hline $91 \cdot 8 \pm 8 \cdot 08$ & $102 \cdot 6 \pm 8 \cdot 08$ & $87 \cdot 3 \pm 8 \cdot 57$ \\
\hline $6 \cdot 8 \pm 0 \cdot 94$ & $7 \cdot 5 \pm 0 \cdot 94$ & $8 \cdot 0 \pm 1 \cdot 00$ \\
\hline $\mathrm{ND}^{2}$ & $0 \cdot 8 \pm 1 \cdot 83$ & $4.5 \pm 1.94$ \\
\hline $174 \cdot 1 \pm 129 \cdot 3$ & $299 \cdot 3 \pm 129 \cdot 3$ & $197 \cdot 4 \pm 137 \cdot 1$ \\
\hline $542 \cdot 3 \pm 163 \cdot 72$ & $1048 \cdot 9 \pm 163 \cdot 72^{*}$ & $487 \cdot 1 \pm 173 \cdot 7$ \\
\hline $93 \cdot 2 \pm 8 \cdot 41$ & $96 \cdot 4 \pm 8 \cdot 41$ & $89 \cdot 8 \pm 8 \cdot 92$ \\
\hline $0 \cdot 61 \pm 0.408$ & $0 \cdot 83 \pm 0 \cdot 41$ & $1 \cdot 51 \pm 0 \cdot 43$ \\
\hline
\end{tabular}

Plasma concentration

Glucagon $(\mathrm{pg} / \mathrm{ml})$ Insulin ( $\mathrm{ng} / \mathrm{ml})$

IGF-I (ng/ml)

IGF-II (ng/ml)

Glucose $(\mathrm{mg} / \mathrm{dl})$

NEFA $(\mu \mathrm{Eq} / \mathrm{l})$

Trigylcerides $(\mathrm{mg} / \mathrm{dl})$

Uric acid (mg/dl)

\section{Tissue IGF-I concentration}

(pg/mg protein)

Liver

Pectoralis major

Gastrocnemius

\section{Hepatic iodothyronine} deiodinase activity

$\mathrm{DI}$ (pmol $\mathrm{rT}_{3}$ deiodinated/mg microsomal protein per min) DIII (fmol $\mathrm{T}_{3}$ deiodinated/mg microsomal protein per min)
$0 \cdot 61 \pm 0 \cdot 408$ 


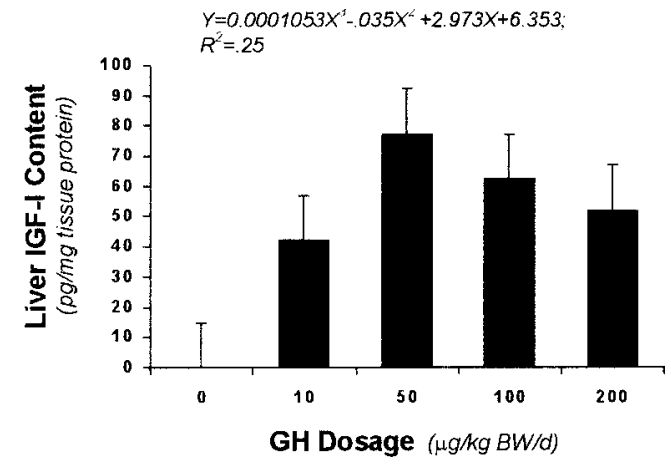

Figure 3 Liver IGF-I protein concentration ( $\mathrm{pg} / \mathrm{mg}$ tissue protein) in 8-week-old, female broiler chickens intravenously infused in a pulsatile pattern for 7 days with $\mathrm{cGH}$ at $0,10,50,100$ or $200 \mu \mathrm{g} / \mathrm{kg}$ BW per day. Tissues were collected on the final day of infusion, immediately following completion of a pulse. Values are $\operatorname{LSM} \pm$ S.E. of the LSM ( $n=9-10$ birds/dosage).

1994)), despite evidence that early events in the GH signaling pathway were intact (tyrosine phosphorylation of JAK2 kinase; Zhou et al. 1998) and despite a significant, dose-dependent increase in hepatic IGF-I protein content, which increased from virtually undetectable levels to approximately 80-fold higher at the maximally effective $\mathrm{GH}$ dosage. These would indicate that GH signal transduction is intact to the point of stimulating IGF-I synthesis in liver, but that release into the circulation is somehow impaired.

There is evidence that thyroid hormones may be important regulators of IGF-I, and affect synthesis, release and/or bioactivity of the growth factor. Methimazoleinduced hypothyroidism decreased circulating IGF-I levels in broilers (Decuypere et al. 1987). Thomas et al. (1993) reported similar serum IGF-I concentrations, but a 70\% reduction in serum IGF-I bioactivity and reduced body weight in hyperthyroid rats compared with control animals. If such a reduction in bioactivity occurred in the present study, a reduction in skeletal muscle protein synthesis would be conceivable, despite no significant alteration in circulating, immunoassayable IGF-I concentrations. Alternatively, $\mathrm{T}_{3}$ decreased IGF-I released by neuronal cells in culture (Binoux et al. 1985), and circulating IGF-I was reduced in chickens administered supplemental $\mathrm{T}_{3}$ (Vasilatos-Younken et al. 1997, Tixier-Boichard et al. 1990). Wolf et al. (1989) demonstrated in hypophysectomized rats that thyroid hormones had major effects on GH-stimulated IGF-I synthesis and secretion, with the pattern depending upon prior exposure to $\mathrm{GH}$ and/or thyroid hormones, and the temporal relationship between GH and thyroid hormone administration. In the latter study, a single injection of $\mathrm{T}_{3}$ alone had little effect on circulating IGF-I levels, whereas a single injection of $\mathrm{T}_{3}$ plus GH slightly increased IGF-I above the level achieved with $\mathrm{GH}$ alone, and a single
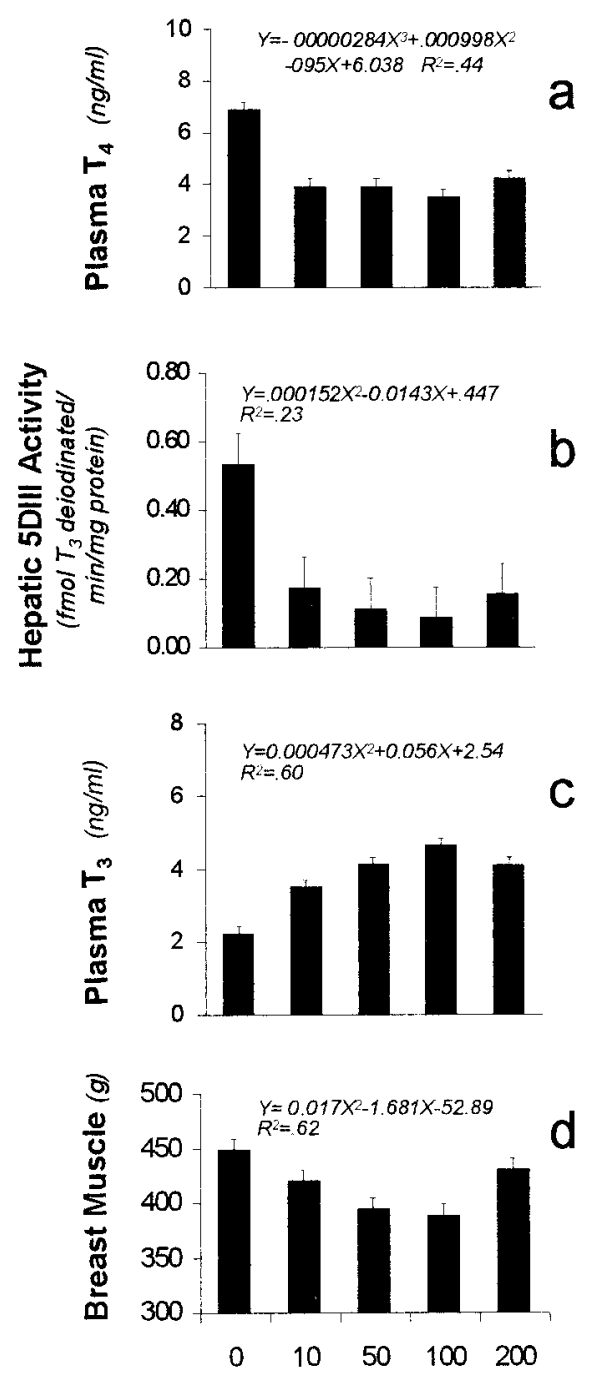

\section{GH Dosage $(\mu g / k g B W / d)$}

Figure 4 Mean (a) plasma $\mathrm{T}_{4}(\mathrm{ng} / \mathrm{ml})$, (b) hepatic DIII deiodinase activity (5 DIII; fmol $\mathrm{T}_{3}$ deiodinated/mg liver microsomal protein per min), (c) plasma $T_{3}(\mathrm{ng} / \mathrm{ml})$, and (d) breast muscle mass $(\mathrm{g})$ in 8-week-old, female broiler chickens intravenously infused in a pulsatile pattern for 7 days with $\mathrm{cGH}$ at $0,10,50,100$ or $200 \mu \mathrm{g} / \mathrm{kg}$ BW per day. Blood and tissue samples were collected on the final day of infusion, immediately following completion of a pulse. Values are LSM \pm S.E. of the LSM ( $n=9-10$ birds/dosage).

injection of $\mathrm{T}_{3}$ following 10 days of $\mathrm{GH}$ treatment substantially lowered IGF-I versus GH-treated, pre- $\mathrm{T}_{3}$ levels (Wolf et al. 1989). As plasma $\mathrm{T}_{3}$ was increased at every GH dosage in the present study, it is not known whether GH enhancement in the absence of increased $\mathrm{T}_{3}$ would successfully effect an increase in circulating IGF-I. It is reasonable to speculate, however, that the apparent inability of exogenous GH to increase circulating IGF-I concentrations in immature, growing chickens, as noted 
Table 5 Hepatic type III iodothyronine deiodinase mRNA and skeletal muscle (pectoralic major) free 3-methyl histidine concentrations ${ }^{1}$ following 7 days of pulsatile i.v. infusion of vehicle (control) or $100 \mu \mathrm{g} \mathrm{CGH/KG} \mathrm{BW}$ per day to 8-week-old, female broiler-strain chickens fed ad libitum, or following 7 days of pulsatile i.v. infusion of vehicle to birds fed ad libitum (control) or restricted to the reduced level of voluntary feed consumption of birds infused with $100 \mu \mathrm{g} \mathrm{CGH} / \mathrm{kg}$ BW per day (pairfed-100)

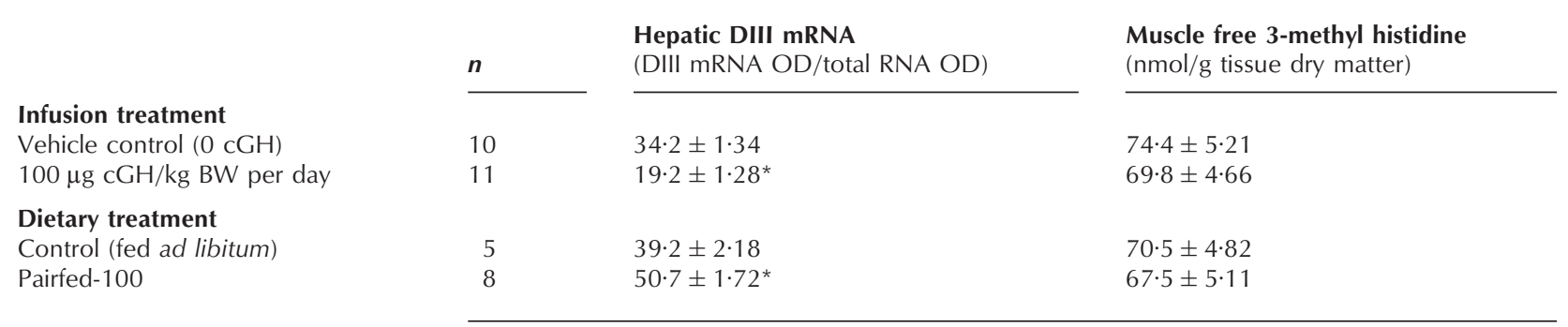

${ }^{1} \mathrm{LSM} \pm$ S.E. of the LSM.

*Significantly different from control $(P<0 \cdot 05)$.

in this and previous studies (for review see VasilatosYounken 1999), is secondary to GH-induced hyperthyroidism.

The metabolic effects of $\mathrm{GH}$ are considered direct actions of the hormone, and evidence of such effects was apparent in GH-infused birds in this study. These included a dose-dependent increase in plasma NEFA concentrations, which was linear over the entire $\mathrm{GH}$ dosage range, and reflects the direct, lipolytic nature of cGH, documented previously in vitro (Campbell \& Scanes 1985, 1987). Although evidence for a hyperglycemic

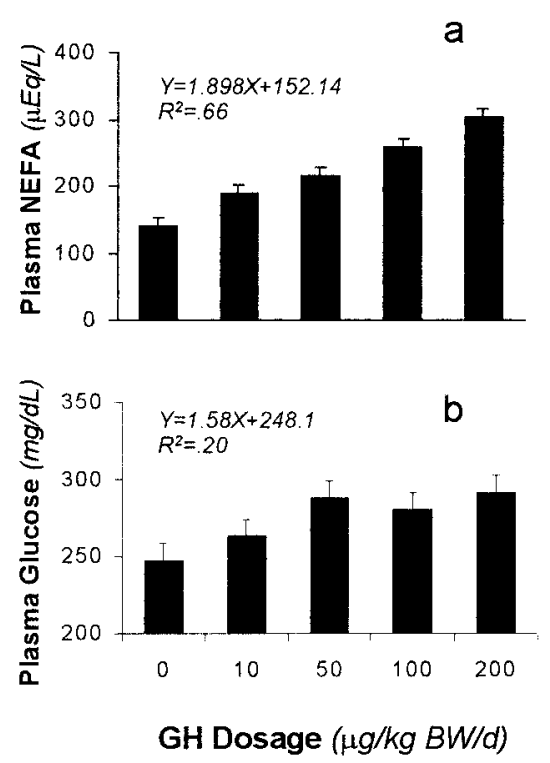

Figure 5 (a) Plasma NEFA ( $\mu \mathrm{Eq} / \mathrm{l})$ and (b) glucose $(\mathrm{mg} / \mathrm{dl})$ concentrations in 8-week-old, female broiler chickens intravenously infused in a pulsatile pattern for 7 days with $\mathrm{cGH}$ at $0,10,50,100$ or $200 \mu \mathrm{g} / \mathrm{kg}$ BW per day. Blood samples were collected on the final day of infusion, immediately following completion of a pulse. Values are LSM \pm S.E. of the LSM $(n=9-10$ birds/dosage). effect of GH was observed, this was in the absence of any significant increase in circulating insulin concentrations, consistent with previous studies from our laboratory with GH infused in a pulsatile pattern (Vasilatos-Younken et al. 1988). This may reflect a direct, gluconeogenic effect on the liver, but does not appear to elicit the diabetogenic response typically observed in mammalian species such as the human (Sonksen et al. 1993) and the pig (Etherton et al. 1993).

Finally, given the significant (44\%) reduction in hepatic DIII mRNA in birds infused with the maximally effective (in terms of thyroid axis responses) $\mathrm{GH}$ dosage, a cohesive and reasonable pathway by which $\mathrm{GH}$ impacts on thyroid hormone metabolism and, ultimately, muscle growth in the chicken emerges. This pathway begins at the pretranslational level of control, with reduced mRNA expression of hepatic 5 DIII resulting in reduced DIII protein product, and reflected in a reduced level of enzyme activity. This decrease in DIII activity contributes to a reduction in the conversion of $\mathrm{T}_{3}$ to its inactive form, thereby elevating circulating $\mathrm{T}_{3}$ levels. Elevated $\mathrm{T}_{3}$ results in TSH-mediated feedback inhibition of circulating $\mathrm{T}_{4}$ concentrations, and impairment of hepatic IGF-I release, with attendant reduced net skeletal muscle deposition.

In summary, the present study clearly demonstrates that $\mathrm{GH}$ does in fact have significant biological effects in the chicken. Most importantly, it underlines the recognition that among these are profound metabolic actions that appear to predominate, and may limit the potential for $\mathrm{GH}$ to elicit positive, IGF-I-mediated skeletal muscle growth in the chicken.

\section{Acknowledgements}

This work was supported by grants from DeGussa Corp., Kennesaw, GA, USA and USDA-NRI Grant No. 9835206-6411 to R V-Y, and by the K. U. Leuven Research Council (Project OT/97/22) to V M D. 


\section{References}

Allen PC \& McMurtry JP 1984 Changes in pancreatic hormones associated with coccidiosis. Poultry Science 63 1129-1135.

Aberle ED \& Stewart TS 1983 Growth of fiber types and apparent fiber number in skeletal muscle of broiler- and layer-type chickens. Growth 47 135-144.

Baumann G 1997 Editorial: Growth without a pituitary? - Lessons from the guinea pig. Endocrinology 138 3575-3576.

Binoux M, Faivre-Bauman A, Lassarre C, Barret A \& Tixier-Vidal A 1985 Triiodothyronine stimulates the production of insulin-like growth factor (IGF) by fetal hypothalamus cells cultured in serum-free medium. Developmental Brain Research 21 319-321.

Bowen SJ, Huybrechts LM, Marsh JA \& Scanes CG 1987 Influence of triiodothyronine and growth hormone on growth of dwarf and normal chickens. Interactions of hormones and genotype. Comparative Biochemistry and Physiology 86A 137-142.

Campbell RM \& Scanes CG 1985 Lipolytic activity of purified pituitary and bacterially-derived growth hormone on chicken adipose tissue in vitro. Proceedings of the Society for Experimental Biology and Medicine 180 513-517.

Campbell RM \& Scanes CG 1987 Growth hormone inhibition of glucagon and cAMP-induced lipolysis by chicken adipose tissue in vitro. Proceedings of the Society for Experimental Biology and Medicine 184 456-460.

Carter WJ, Benjamin WSW \& Faas FH 1980 Effect of experimental hyperthyroidism on protein turnover in skeletal and cardiac muscle. Metabolism 29 910-915.

Clayton BE \& Worden JA 1960 Growth in young, hypophysectomized guinea pigs. Journal of Endocrinology 20 36-47.

Cravener TL \& Vasilatos-Younken 1989 A method for catheterization, harnessing and chronic infusion of undisturbed chickens. Laboratory Animals 23 270-274.

Darras VM, Visser TJ, Berghman LR \& Kuhn ER 1992 Ontogeny of type I and type III deiodinase activities in embryonic and posthatch chicks: relationship with changes in plasma triiodothyronine and growth hormone levels. Comparative Biochemistry and Physiology 103A 131-136.

Darras VM, Rudas P, Visser TJ, Hall TR, Huybrechts LM, Vanderpooten A, Berghman LR, Decuypere E \& Kuhn ER 1993 Endogenous growth hormone controls high plasma levels of 3, $3^{\prime}, 5$-triiodothyronine $\left(T_{3}\right)$ in growing chickens by decreasing the $\mathrm{T}_{3}$-degrading type III deiodinase activity. Domestic Animal Endocrinology 10 55-65.

Darras VM, Cokelaere M, Dewil E, Arnouts S, Decuypere E \& Kuhn ER 1995 Partial food restriction increases hepatic inner ring deiodinating activity in the chicken and the rat. General and Comparative Endocrinology 100 334-338.

Decuypere E, Buyse J, Scanes CG, Huybrechts L \& Kuhn ER 1987 Effects of hyper- or hypothyroid status on growth, adiposity and levels of growth hormone, somatomedin C and thyroid metabolism in broiler chickens. Reproduction, Nutrition and Development 27 $555-565$.

Du SJ, Gong ZY, Fletcher GL, Shears MA, King MJ, Idler DR \& Hew CL 1992 Growth enhancement in transgenic Atlantic salmon by the use of an 'all fish' chimeric growth hormone gene construct. Bio/Technology 10 176-181.

Etherton TD \& Bauman DE 1998 Biology of somatotropin in growth and lactation of domestic animals. Physiological Reviews 78 745-761.

Etherton TD, Louveau I, Sorenson MT \& Chaudhuri S 1993 Mechanisms by which somatotropin decreases adipose tissue growth. American Journal of Clinical Nutrition 58 287S-295S.

Hasselgren P-O, Adlerberth A, Angeras U \& Stenstrom G 1984 Protein metabolism in skeletal muscle tissue from hyperthyroid patients after preoperative treatment with antithyroid drug or selective $\beta$-blocking agent. Results from a prospective, randomized study. Journal of Clinical Endocrinology and Metabolism $59835-839$.
Johansson JO, Oscarsson J, Bjarnason R \& Bengtsson BA 1996 Two weeks of daily injections and continuous infusion of recombinant human growth hormone $(\mathrm{GH})$ in $\mathrm{GH}$-deficient adults: I. Effects on insulin-like growth factor-I (IGF-I), GH and IGF-I binding proteins, and glucose homeostasis. Metabolism (Clinical and Experimental) 45 362-369.

Johnson RJ 1988 Diminution of pulsatile growth hormone secretion in the domestic fowl (Gallus domesticus): evidence for sexual dimorphism. Journal of Endocrinology 119 101-109.

Jorgensen JO, Moller J, Laursen T, Orskov H, Christiansen JS \& Weeke J 1994 Growth hormone administration stimulates energy expenditure and extrathyroidal conversion of thyroxine to triiodothyronine in a dose-dependent manner and suppresses circadian thyrotropin levels: studies in GH-deficient adults. Clinical Endocrinology 41 609-614.

Kuhn ER, Berghman LR, Moons L, Vandesande F, Decuypere E \& Darras VM 1993 Hypothalamic and peripheral control of thryoid function during the life cycle of the chicken. In Avian Endocrinology, pp 29-46. Ed. PJ Sharp. Bristol, UK: Society for Endocrinology.

Leonard JL \& Visser TJ 1986 Biochemistry of deiodination. In Thyroid Hormone Metabolism, pp 189-229. Ed. G Hennemann. New York: Marcel Dekker.

deLuze A \& Leloup J 1984 Fish growth hormone enhances peripheral conversion of thyroxine to triiodothyronine in the eel (Anguilla anguilla L.). General and Comparative Endocrinology 56 308-312.

McMurtry JP, Rosebrough RW \& Steele NC 1983 A homologous radioimmunoassay for chicken insulin. Poultry Science 62 697-701.

McMurtry JP, Francis GL, Upton FZ, Rosselot G \& Brocht DM 1994 Developmental changes in chicken and turkey insulin-like growth factor-I (IGF-I) studied with a homologous radioimmunoassay for chicken IGF-I. Journal of Endocrinology 142 225-234.

McMurtry JP, Rosebrough RW, Brocht DM, Francis GL, Upton Z \& Phelps P 1998 Assessment of developmental changes in chicken and turkey insulin-like growth factor-II by homologous radioimmunoassay. Journal of Endocrinology 157 463-473.

May JD 1980 Effect of dietary thyroid hormone on growth and feed efficiency of broilers. Poultry Science 59 888-892.

Mitchell ML, Guillemin R \& Selye H 1954 The effect of somatotropic hormone in the growth of normal and hypophysectomized guinea pigs. Endocrinology 54 111-114.

Moellers RF \& Cogburn LA 1995 Chronic intravenous infusion of chicken growth hormone increases body fat content of young broiler chickens. Comparative Biochemistry and Physiology $110 \mathrm{~A}$ 47-56.

Moller J, Jorgensen JO, Moller N, Christiansen JS \& Weeke J 1992 Effects of growth hormone administration on fuel oxidation and thyroid function in normal man. Metabolism (Clinical and Experimental) 41 728-731.

Morrison WL, Gibson JNA, Jung RT \& Rennie MJ 1988 Skeletal muscle and whole body protein turnover in thyroid disease. European Journal of Clinical Investigation 18 62-68.

Moussavi R 1990 Neonatal hyperthyroidism enhances growth of the heart but not of skeletal muscle. Mechanisms of Ageing and Development 52 1-10.

Nickel R, Schummer A \& Seiferle E 1977 Anatomy of the Domestic Birds, pp 32, 36-37, 40-60. Berlin: Verlag Paul Parey.

Peebles ED, Burke WH \& Marks HL 1988 Effects of recombinant chicken growth hormone in random bred meat-type chickens. Growth, Development and Aging 52 133-138.

Rahman MA, Mak R, Ayad H, Smith A \& Maclean N 1998 Expression of a novel piscine growth hormone gene results in growth enhancment in transgenic tilapia (Oreochromis niloticus). Transgenic Research 7 357-369.

Rosselot G, McMurtry JP, Vasilatos-Younken R \& Czerwinski 1995 Effect of exogenous chicken growth hormone $(\mathrm{cGH})$ administration on insulin-like growth factor-I (IGF-I) gene expression in domestic fowl. Molecular and Cellular Endocrinology 114 157-166. 
Sato N, Murata K, Watanabe K, Hayami T, Kariya Y, Sakaguchi M, Kimura S, Nonaka M \& Kimura A 1988 Growth-promoting activity of tuna growth hormone and expression of tuna growth hormone cDNA in Escherichia coli. Biotechnology and Applied Biochemistry 10 385-393.

Sonksen PH, Russell-Jones D \& Jones RH 1993 Growth hormone and diabetes mellitus. A review of sixty-three years of medical research and a glimpse into the future? Hormone Research 40 68-79.

Thomas MR, Miell JP, Taylor AM, Ross RJM, Arnao JR, Jewitt DE \& McGregor AM 1993 Endocrine and cardiac paracrine actions of insulin-like growth factor-I (IGF-I) during thyroid dysfunction in the rat: is IGF-I implicated in the mechanism of heart weight change during abnormal thyroid function? Journal of Molecular Endocrinology 10 313-323.

Tixier-Boichard M, Decuypere E, Huybrechts L, Kuhn E \& Merat P 1990 Effects of dietary $T_{3}$ on growth parameters and hormone levels in normal and sex-linked dwarf chickens. Domestic Animal Endocrinology 7 573-586.

Van der Geyten S, Sanders JP, Kaptein E, Darras VM, Kuhn ER, Leonard JL \& Visser TJ 1997 Expression of chicken hepatic type I and type III iodothyronine deiodinases during embryonic development. Endocrinology 138 5144-5152.

Van der Geyten S, Buys N, Sanders JP, Decuypere E, Visser TJ, Kuhn ER \& Darras VM 1999a Acute pretranslational regulation of type III iodothyronine deiodinase by growth hormone and dexamethasone in chicken embryos. Molecular and Cellular Endocrinology 147 49-56.

Van der Geyten S, Van Rompaey E, Sanders JP, Visser TJ, Kuhn ER \& Darras VM $1999 b$ Regulation of thyroid hormone metabolism during fasting and refeeding in the chicken. General and Comparative Endocrinology 116 272-280.

Vasilatos-Younken R 1986 Preparation and culture of dispersed avian pituitary cells, and age-related changes in donor pituitary weight and growth hormone content. General and Comparative Endocrinology 64 99-106.

Vasilatos-Younken R 1999 Absence of growth hormone-induced avian muscle growth in vivo. Poultry Science 78 759-768.
Vasilatos-Younken R \& Zarkower PG 1987 Age-related changes in plasma immunoreactive growth hormone secretory patterns in broiler pullets. Growth $\mathbf{5 1} 171-180$.

Vasilatos-Younken R \& Scanes CG 1991 Growth hormone and insulin-like growth factors in poultry growth: Required, optimal or ineffective? Poultry Science 70 1764-1780.

Vasilatos-Younken R, Cravener TL, Cogburn LA, Mast MG \& Wellenreiter RH 1988 Effect of pattern of administration on the response to exogenous pituitary-derived chicken growth hormone by broiler-strain pullets. General and Comparative Endocrinology $\mathbf{7 1}$ 268-283.

Vasilatos-Younken R, Dunnington EA, Siegel PB \& McMurtry JP 1997 Tissue-specific alterations in insulin-like growth factor-I concentrations in response to $3,3^{\prime}, 5$-triiodo-L-thyronine supplementation in the growth hormone receptor-deficient sex-linked dwarf chicken. General and Comparative Endocrinology 105 31-39.

Wang X, Day JR, Zhou Y, Beard JL \& Vasilatos-Younken R 2000 Evidence of a role for neuropeptide $\mathrm{Y}$ and monoamines in mediating the appetite-suppressive effect of GH. Journal of Endocrinology 166 621-630.

Wassner SJ, Schlitzer JL \& Li JB 1980 A rapid, sensitive method for the determination of 3-methylhistidine levels in urine and plasma using high-pressure liquid chromatography. Analytical Biochemistry 104 284-289.

Wolf M, Ingbar SH \& Moses AC 1989 Thyroid hormone and growth hormone interact to regulate insulin-like growth factor-I messenger ribonucleic acid and circulating levels in the rat. Endocrinology $\mathbf{1 2 5}$ 2905-2914.

Zhou Y, Wang X, McMurtry JP \& Vasilatos-Younken R 1998 Induction and activation of JAK2 protein occur with chronic exposure to $\mathrm{GH}$, despite lack of an anabolic response in chicken skeletal muscle. Poultry Science 77 (Suppl 1) 33, No. 124.

Received 20 October 1999
Accepted 18 April 2000 